УДК 786.2+78.03+78.085.21

DOI https://doi.org/10.31723/2524-0447-2021-32-1-14

Інна Анатоліївна Тимченко-Бихун

ORCID: 0000-0001-9139-2203

кандидат мистецтвознавства, доцент, професор кафедри історії музики, декан факультету мистецтва співу та джазу

Київської муніципальної академії музики імені Р. М. Глієра inna_timchenko@ukr.net

\title{
ЕПІСТОЛЯРІЇ М. ГЛІНКИ ОСТАННІХ РОКІВ: ОСОБИСТІСНІ МОТИВИ ТА ТВОРЧІ ІНТЕНЦІЇ
}

Мета роботи - за посередництва уважного проникнення в характерні теми й мотиви епістоляріїв М. Глінки завершального триріччя (1854-1857 рр.) виявити сутнісні смисли його світосприйняття та визначити художні концепти стилю композитора пізнього творчого періоду. Методологія дослідження полягає у застосуванні методики культурологічного коментаря, розробленої в праиях С. Тишка у сnівавторстві із С. Мамаєвим, Г. Куколь як аналітичного коментаря до тематики епістоляріїв Глінки 1854-1857 рр., що розглядаються як смислова цілісність, виокремлена з корпусу епістолярних текстів. Також залучені позиції сучасних напрямів музикознавчої науки, спрямовані на дослідження історії «в людському вимірі»: методики епістолографії (М. Копиия), теорії «вікового музикознавства» (Н. Савицька). Наукова новизна полягає в прицільному розгляді текстів епістолярної спадщини М. Глінки завершального триріччя та виявленні константних тем у листуванні з близьким колом адресатів, які мають безпосередні та опосередковані зв'язки з творчістю композитора; у формуванні уяви про світоглядні установки композитора-романтика та підсумкові інтенції його творчості останніх трьох років; у долученні до наукових розвідок творчої біографії Глінки комплексу ідей сучасних музикознавчих концепцій, спрямованих на розуміння ролі особистості в історії. Висновки. Осмислення епістолярної спадщини Глінки як цілісності дозволяє виокремити корпус листів 1854-1857 рр., звернених до довірених адресатів; виявити ключові установки підсумкового періоду творчості Глінки та встановити відкриту перспективу його нових творчих пошуків. Ностальгічні мотиви та образи-спогади, що постають у листах Глінки останнього триріччя нотою печалі та смутку, втілюються у п'єси світлим і гармонійним настроєм, а творчим підсумком стає твір-кантата «Молитва» релігійно-філософського змісту. 
Ключові слова: епістолярії М. Глінки останніх років, коментар до творчого доробку, теми та мотиви епістолярної спадщини, корпус листів 1854-1857 рр., пізній композиторський стиль, ностальгічні мотиви та образи-спогади.

Tymchenko-Bykhun Inna Anatoliivna, Candidate of Art Studies, Associate Professor, Professor at the Department of Music History, Dean of the Faculty of Art of Singing and Jazz of R. Glier Kyiv Municipal Academy of Music

Epistolary of the last years M. Glinka: personalized motives and creative intentions

Working purpose: through the mediation of attentive penetration into the characteristic themes and the motives of M. Glinka's epistolary for the final three-year period (1854-1857), it is necessary to identify the essential meanings of his perception of the world and notice the artistic concepts of the composer's style of the late creative period. The research methodology consists in the application of the culturological commentary technique, which was developed in the S. Tyshko works, also in co-authored by S. Mamaiev and G. Kukol, as an analytical commentary on the subject of Glinka's epistolary (1854-1857), and which are considered as semantic integrity isolated from the corpus of epistolary texts. Also attracted are the positions of the modern direction of musicology, aimed at studying history "in the human dimension": methods of epistolography (M. Kopytsa), the theory of "age-related music studies" ( N. Savytska). The academic novelty lies in the purposeful examination of the texts of the epistolary heritage of M. Glinka of the final three years and the identification of constant themes in correspondence with a close circle of addressees who have direct and indirect connections with the work of the composer; in the formation of an idea of the ideological attitudes of the romantic composer and the final intentions of his work over the past three years in the introduction to scientific research of Glinka's creative biography of a set of ideas of modern musicological concepts aimed at understanding the role of personality in history. Conclusions. Comprehension of the epistolary heritage of Glinka as a whole makes it possible to single out the corpus of letters during 1854-1857, conversion to trusted addressees; identification of the key attitudes of the final period of Glinka's work and the establishment of an open perspective of his new creative searches. Nostalgic motives and images-memories that have arisen in Glinka's letters of the last three years with a note of grief and sadness are embodied in plays of a light, harmonious mood. And the creative result is the final major work of the cantata "Prayer" of religious and philosophical content.

Key words: M. Glinka's epistolary of recent years, comments on creativity, themes and motives of the epistolary heritage, corpus of letters from 1854-1857, late composer's style, nostalgic motives and images-memories.

Актуальність теми дослідження. Літературна та епістолярна творчість М.І. Глінки є значним корпусом текстів у кількісному й сутнісному значеннях, адже є вагомою частиною його 
спадщини, опосередкованим коментарем до музичних опусів та одним із мистецьких одкровень епохи романтизму. Окрім відомих мемуарів композитора, збереглося досить багато листів різних років; часто численні подорожі мотивували Глінку до розлогих розповідей про події побутового та творчого життя або ж і відволікали від епістолярної діяльності.

Хронологічні періоди творчості у взаємодії з етапами змін світосприйняття композитора представляють нам дещо різні особистісні установки Глінки, які багато в чому відповідають загальним психологічним тенденціям вікових змін життєвих пріоритетів людини. Італійські листи молодого композитора сповнені радості, пошуку яскравих вражень, безмежної зацікавленості музикою, природою та людьми; епістолярії зрілого віку сконцентровані на важливих творчих подіях, власних планах, мріях, бажаннях, а також хворобах і лікуванні, справах друзів та рідних. А елегійні настрої, притаманні великим фортепіанним творам початку останнього десятиріччя, римуються з ностальгічними мотивами листів композитора. Н. Савицька, концентруючись на розгляді «вікових універсалій», переконливо доводить тезу про те, що «принцип переходу від однієї вікової фази до іншої втілює ідею трансцендентного перетворення» [4, с. 13]. Виокремити останнє триріччя епістоляріїв композитора з корпусу текстів цього спадку і виявити через характерні теми й мотиви сутність композиторського світосприйняття - завдання цієї статті.

Інноваційна методика дослідження творчої біографії та музичного спадку М. Глінки була сформована в працях вітчизняних авторів, зокрема С. Тишка у співавторстві із С. Мамаєвим [5] та Г. Куколь [6]. Культурологічний коментар до текстів «Записок» М. Глінки став основою сучасного наукового напряму, в якому біографічні факти та творчі події життя композитора вписані в простір європейської романтичної культури. Новітні теорії української музичної науки, як-от епістолографія (М. Копиця) [3] та «вікове музикознавство» (Н. Савицька) [4], формують осучаснене уявлення про історію «в людському вимірі» (М. Копиця). Ці концепції також стверджують вагомість мемуарних документів та епістолярію. Так, М. Копиця у фундаментальному труді відзначає «не тільки активізацію процесів вивчення факту (що саме по собі важливо), а й узагальнення за формулою: від концепції документа до нового осмислення історії [4, с. 6]. Теорія «вікового 
музикознавства» Н. Савицької, в якій «індивідуальний хронос» $€$ ефективним інструментом «пізнання мікросвіту мистецької особистості» [4, с. 3], формуючи уявлення про «психовікові проекції становлення композиторської особистості», сконцентрована, зокрема, на специфіці зміни «модусу творчої свідомості на тлі циклічності вікових фаз» [4, с. 13].

Це відкриває перспективи для оновлювального сучасного розуміння творчої долі романтичного композитора ХІХ століття. Листи М. Глінки 1854-1857 рр. є своєрідним текстовим цілим та коментарем до композиторських мистецьких задумів. «XIX століття монументалізує царину епістолярію». - стверджує Н. Савицька, - Листи - віддзеркалення особистого духовного континууму, жанр освідчень, відображень психологічного стану, інтенцій, взаємин із сучасниками» [4, с. 11].

Мета дослідження - за посередництва уважного проникнення в характерні теми й мотиви епістоляріїв М. Глінки завершального триріччя (1854-1857 рр.) виявити сутнісні смисли його світосприйняття та визначити художні концепти стилю композитора пізнього творчого періоду.

Наукова новизна. Вперше дослідження творчої біографії М. Глінки сконцентровано на окремій частині його епістолярної спадщини; долучення комплексу ідей сучасних музикознавчих концепцій, спрямованих на культурологічний коментар до літературно-документальних творів митця та розуміння ролі особистості в історії, дозволяє уточнити уявлення про світоглядні установки композитора-романтика та підсумкові інтенції його творчості останніх трьох років.

Виклад основного матеріалу. Листи М.І. Глінки останнього триріччя (з 1 січня 1854 р. до 15 січня 1857 р.) у виданні «Літературні твори та листування» виокремлені у том II-Б (другий напівтом [2]), що зумовлено великим обсягом його епістоляріїв та інших документів, включених у друкування (ділові папери, дарчі написи та ін.). Такий розподіл видається логічним ще з однієї причини: листи цих років (як літературно-документальне ціле) відрізняє від усього епістолярного масиву низка ознак, за якими вони вбудовані в структуру загального як мікроструктура зі своїми внутрішніми законами.

Зважаючи на настрій позначених листів, можна зробити висновок, що цей період стає для Глінки багато в чому часом підсумків творчого й життєвого шляху, незважаючи на те, що композиторові у 1854 році має виповнитися лише 50 років. 
Начебто відчуваючи поступовий спад вітальної енергії, композитор усе частіше говорить про втому, вік, хвороби, відмову від бездумних розваг, що узагальнюється в мотиви смирення з власною долею, а часто - в артикульоване бажання їі християнського прийняття. Дешо гіпертрофоване відчуття власного віку людиною, явно далекою від старості, не є рідкістю серед романтиків. Досить навести міркування двох романтиків, щирість яких не викликає сумнівів, адже вони викладені в довірчому листуванні та описують суб'єктивне відчуття.

38-річний Ф. Шопен писав із Шотландії 18 серпня 1848 р. одному з найближчих друзів - польському композитору і піаністу Ю. Фонтані: «Ми - старі цимбали, на яких час і обставини розігрували свої злощасні трелі. Так, старі цимбали ${ }^{1}$, хоча ти й будеш відхрешуватися від такої компанії. Однак це не віднімає ані краси, ані шляхетності: la table d'harmonie (дека (франц.). - I.T.-Б.) чудова, тільки струни пообривались та деякі кілки повискакували. Біда лише в тому, що ми роботи славного скрипкового майстра, якого-небудь Страдіварія sui generis (свого роду (лат.). - I.T.-Б.), якого вже немає на світі, щоб полагодити нас. Ми не вміємо видавати нових звуків під незграбними руками і душимо в собі те, чого за відсутності майстра ніхто вже не витягне з нас» [7, с. 237-238].

В. Жуковський, якому виповнилось 49 років, сформулював ясніше: «Я не постарів і не жив, а потрапив у старі, - писав у день свого народження (29 січня 1833 р.) Зонтаг. - Життя моє було взагалі так однаково, так само на себе схоже, що я ще не залишав молодості, а ось уже треба сказати рішуче «прости» цій молодості та бути старим, не будучи старим» [1, с. 389].

Мабуть, схоже почувається Глінка. Він планує поїздки для поправки здоров'я та позбавлення від негативних емоцій, пов'язаних із петербурзькими розчаруваннями, та для конкретних музичних цілей. Щодо поїздки в Німеччину в січні 1856 року пише К.А. Булгакову: «Цю подорож я зроблю не тільки для виправлення поганого мого здоров'я, а й для деяких музичних довідок» [2, с. 104]; пізніше - П.А. Бартенєвій: «У кінці цього місяця мій доктор мене рішуче виганяє за кордон» [2, с. 120], В.П. Енгельгардту: «Тепер для мене pittoresque (мальовничість (франц.). - I.T.-Б.) в стороні,

1 У коментарі до листа відзначена можливість гри слів, адже польською «суmbał»- олух, дурень [7, с. 238]. 
а головне comfort (комфорт (франц.). - I.T.-Б.) і спокій...» [2, с. 124]. Та ще літом емоційно зізнається сестрі Людмилі Іванівні: «Здоров'я важливіше за всі музики у світі» [2, с. 94]. Цікавою є поява біблеїзму в листі Глінки К. Булгакову від 9 вересня 1955 р.: «Дух бадьорий, а плоть немічна; весь я в якомусь оглумі, тобто хандрі. Справжнє бридко, а про майбутнє не смію загадувати. Хотів було поїхати до Варшави: c'est le paradis des hommes vieux ou de ceux qui sont sur le retour (Це рай для людей старих, або тих, хто старіє (франц.) - I.T.-Б.) [2, с. 98]. Початкові слова листа цитують євангельські строки: «Пильнуйте й моліться, щоб не ввійти в спокусу: дух бадьорий, плоть же немічна» (Мф. 26, 41). Цей приклад виявляє риси епістолярного стилю Глінки, який демонструє «інтегрований тип мислення» [4, с. 15], притаманний пізній творчості художника, адже «стиль є максимально індивідуалізованою формою персоніфікації власної світоглядної позиції» [4, с. 23].

Відчуття тиску віку, розчарування - мотив, що повторюється: «Воно, звичайно, так, адже і дерева зелені, і клімат нібито краще - все так, але старість долає» (О.В., В.В., Д.В. Стасовим та О.М. Серову, Берлін, близько 15 червня 1856 р., [2, с. 137]). Йому протистоять надії на краще та прориви творчої енергії: «Досади, засмучення і страждання мене погубили, і я рішуче впав духом (demoralize). ... До речі, було б мені діла попрацювати 3 Деном над стародавніми церковними тонами... - це б повело мене до гарних результатів» (В.П. Енгельгардту, Петербург, від 29 листопада 1855 р. [2, с. 102]); або: «Всемогутній може сподобити мене зробити церковну російську музику» (Л. Шестаковій, Берлін, від 15 липня 1856 р., [2, с. 153]); також: «Я хворий ... живу єдино надією втекти на Захід, в кінці квітня...» (К.А. Булгакову, Петербург, від 20 березня 1856 р. [2, с. 114]).

Підсумування життєвих мотивів та інтегрованість стилю цементують епістолярії Глінки 1854-1857 рр. в окремий «завершений» блок. Ставлячись серйозно, але й досить іронічно до своїх вічних нездужань, композитор неодноразово висловлює смиренне ставлення до власної втоми, нудьги, хвороби, а загалом - до віку, в якому ці хвороби, на його погляд, неминучі («за старою дурною звичкою хворів» (А.П. Керн, Петербург, 1 лютого 1856 р. [2, с. 106]), «мені бродити по світлу набридло» (В.Н. Кашпєрову, Берлін, 10 липня 1856 р. [2, с. 148]), «мені вже 50 років і пора честь знати» (В.П. Енгельгардту, Царське 
Село, 2 червня 1854 року [2, с. 28])). Зрідка бажання мандрів, що виникає, зупиняється усвідомленням: «Ті місця, де було мені добре, нагадають про мою втрачену молодість; ті ж, де було горе, не варто бачити» (з листа Л.І. Шестаковій, Петербург, 5 червня 1855 р. [2, с. 75]).

Підсумовуючи життя, Глінка повертає своїй колишній коханій К.Е. Керн листи через М.С. Кржисевич, чим перегортає одну 3 найромантичніших любовних сторінок: «...Я ретельно зібрав усі листи К. Е. К, вони тепер зберігаються у сестри; приїжджайте же швидше за ними; я впевнений: повернувши ці листи, ви чимало заспокоїте вашу приятельку» (з листа М.С. Кржисевич, Царське Село, 2 червня 1845 р.) [2, c. 27].

Та саме у цей день починає роботу над «Записками», про що інформує Д.Д. Стасова (Царське Село, 2 червня 1854 р. [2, с. 29]). У літературно-документальному творі композитор у спогадах заново переживає крок за кроком усі події свого життя, структуруючи їх за власною чіткою логікою (одним із важливих сюжетів «Записок» стає тема мандрів, яка викривається в чотиричастинному дослідженні С. Тишко у співавторстві з С. Мамаєвим, Г. Куколь (див., наприклад: [5; 6])). Так, щодо світосприйняття пізнього стилю Н. Савицька пише: «Змінюється не лише специфіка художнього мислення, іншим стає образ мития, який може бути стражденним і радісним, сумним і просвітленим, філософськи самозаглибленим і наївним. Перевага віддається усьому, шо відстоялося, пройшло випробування часом; рефлексивний погляд переважно концентрується на власному минулому» [4, с. 14].

У цей же період він готує романси до видання, ретельно вивіряючи їх, про що повідомляє в листі від 2 листопада 1854 року В.П. Енгельгардту [2, с. 41]; саме це друкування виявилося найбільш повним із прижиттєвих видань романсів Глінки (дані про це наведені у коментарях до листа [2, с. 42]). Він продовжує переробляти свої твори - «діток»: «Не дивлячись на страждання, в деякі вільні від катувань моменти я приводжу в порядок мої твори»; наприклад, Глінка заново інструментує «Вальс-фантазію», роблячи вже третю редакцію партитури (з листа Н.В. Кукольнику від 18 березня 1856 р. [2, c. 113]).

Глінка наполягає на примиренні сестер, залагоджуючи їх відносини [2, с. 86]. А 14 липня 1855 року просить Л.І. Шеста- 
кову надіслати йому портрети батьків [2, с. 89]; думки про смерть усе частіше виникали в композитора, про що пише у спогадах Л.І. Шестакова [2, с. 80].

Мотиви ностальгії (туги за рідними, домом, за власним минулим) породжують музичні образи-спогади фортепіанних мініатюр «Дитяча полька» 1854 р., «Андалузький танець» 1855 р., звернених до вражень щасливих років. Ностальгія - один із лейтмотивів листів композитора, що часто йде поруч із пошуками спокою. 3 листа Л.І. Шестаковій від 1 січня 1854 року, Париж: «Ось і новий рік - рік нашого побачення, якщо бог дасть змогу... Про себе писати нічого живу смирно, домоседно й самотньо» [2, с. 11]; від 16 січня: «Дай господи ... нам побачитися, а потім, як знати, може бути, доведеться нам із тобою побувати і в Італії..» [2, с. 13]; від 2 лютого: «Шум світу, театри, навіть подорожі, все мені набридло, жадаю тихого життя в колі своїх» [2, с. 14]; від 16 лютого: «Ось і кінець лютого - завтра березень, значить, весна, а з нею і втішна думка швидкого повернення на батьківщину. Вельми зело набридло...» [2, с. 15].

А ось лист М.С. Кржисевич від 4 березня: «Отже, моя хандра не просто англійський сплін, а більше - ностальгія, хвороба швейцарців. Дійсно, ось уже рік, як я не живу, а страждаю - на щастя, на днях залишу Париж і з радістю прагну на батьківщину» [2, с. 18]; Л.І. Шестаковій від 28 квітня, Варшава: «Ось мене й покарав господь тугою за вітчизною тепер я живу однією думкою скорого побачення з тобою і нашими» [2, с. 25].

Але за законами романтичних антиномій усі труднощі, туга за минулим, хвороби й тяжкість віку перетворюються в ліричні й світлі або танцювальні фортепіанні та камерно-вокальні мініатюри Глінки. Переосмислюються в звернення до християнського етичного концепту подолання відчаю та просвітлення через молитву у вершинному творі останніх років кантаті «Молитва» на сл. М. Лермонтова для мецо-сопрано, хору та оркестру 1855 р. 3 його релігійно-філософським сюжетом. Затихають у духовних хорах 1856 р. «Да ісправиться молитва моя», «Ектенія перша» та у роботі Глінки із З. Деном над церковною музикою в берлінські місяці $1856 \mathrm{p}$.

Коментар щодо цього авторів другої частини «Мандрів Глінки» С. Тишка та С. Мамаєва виглядає вичерпним. «Взагалі ж, - пишуть науковці, - причини інтересу Глінки до тих 
пластів музики, в яких так чи інакше ще жила середньовічна традиція, стануть більш зрозумілі, якщо враховувати одну важливу їх відмінність від музики нового часу. На неї звернула увагу Н.О. Герасимова-Персидська: «Якщо нова музика сфокусована на слухачеві в залі, спрямована до нього, то середньовічний спів має зворотну спрямованість (від людини до трансцендентного)» [5, с. 96].

Висновки. Епістолярії Глінки 1854-1857 рр. розкривають особистісний і художній світ митця з темами та мотивами, які найбільш хвилюють його; аналітичний розгляд листів останніх років у контексті подій творчої біографії допомагає усвідомити специфіку світосприйняття композитора та іiі відповідність таким інтенціям пізнього творчого віку, як «апеляція до світової культури та глобальних проблем буття», «відтворення особистісно значущого минулого»; «підсумкова концептуалізація власного життя» [4, с. 15].

Ностальгічні мотиви та образи-спогади, що постають у листах Глінки останнього триріччя нотою печалі та смутку, втілюються у п'єси світлого, гармонійного настрою. А творчим підсумком стає фінальний твір-кантата «Молитва» релігійно-філософського змісту.

Але духовні хори 1856 року та робота над церковною музикою, якій здійснитися не судилося, - свідчення оновленої композиторської енергії та символічно відкритої творчої перспективи у майбутнє православної музики.

\section{СПИСОК ЛІТЕРАТУРИ}

1. Веселовский А.Н. В.А. Жуковский: Поэзия чувства и «сердечного воображения». Москва; Санкт-Петербург : Центр гуманитарных инициатив, 2016. 512 с. (Серия «Российский Пропилеи»). URL: https://books.google.com.ua/books

2. Глинка М.И. Полное собрание сочинений. Литературные произведения и переписка. Москва : Музыка, 1975. Т. ІІБ: Письма 1853-1857. Документы. 400 с.

3. Епістолярна спадщина: У 2 т. Упорядник і автор вст. статті М. Копиця. Київ, 2002. Т. I: Борис Лятошинський - Рейнгольд Гліер. Листи (1914-1956). 768 с.

4. Савицька Н. В. Вікові аспекти композиторської життєтворчості : автореф. дис. ... докт. мистецтвознавства: 17.00.03. Київ : НМАУ ім. П.І. Чайковського, 2010. 40 с.

5. Тышко С. В., Мамаев С. Г. Странствия Глинки. Комментарий к «Запискам». Київ : Задруга, 2002. Ч. II: Глинка в Германии, или Апология романтического сознания. 509 с. 
6. Тышко С.В., Куколь Г.В. Странствия Глинки. Комментарий к «Запискам». Ч. ІІІ. Путешествие на Пиренеи или испанские арабески. Київ, 2011. 544 с.

7. Шопен Ф. Письма: в 2-х т. / Сост., комментарии, статьи и аннотированный словарь имен Г.С. Кухарского. 3-е изд. Москва : Музыка, 1984. Т. 2. 461 с.

\section{REFERENCES}

1. Veselovskiy, A. N. (2016). V. A. Zhukovsky: Poetry of feeling and «heart's imagination». M.; SPb.: Center for Humanitarian Initiatives, 2016 (Series "Russian Propylaea") [in Russian]. Retrieved from https://books.google.com.ua/books

2. Glinka, M. I. (1975). Full composition of writings. Literary works and correspondence. M.: Music, 1975. Vol. II B: Letters 1854 - 1857. Documents [in Russian].

3. Kopytsia, M. (Eds.). (2002). Epistolary decline. Vol. I: Boris Lyatoshinsky - Reingold Glier. Letters (1914 - 1956). Kiev, 2002 [in Ukrainian].

4. Savitska, N. V. (2010). Age aspects of the composer's life. Extended abstract of doctor's thesis. Kiev, 2010 [in Ukrainian].

5. Tyshko, S. V., Mamaev, S. G. (2002). Glinka's wanderings. Commentary on the "Notes". Kiev: Zadruga, 2002. Part. II. Glinka in Germany, or Apology of Romantic Consciousness. [in Russian].

6. Tyshko, S. V., Kukol, G. V. (2011). Glinka's wanderings. Commentary on the «Notes». Kiev, 2011. Part III. Travel to Pyrenees or Spanish Arabesques. [in Russian].

7. Shopen, F. (1984). Letters: in 2 volumes. G. S. Kukharskiy (Ed.). M. : Muzyka, 1984. Vol. 2 [in Russian]. 